\title{
AUTUMN, WINTER AND SPRING SOIL TEMPERATURES IN OKSTINDAN, NORWAY*
}

\author{
By Charles Harris \\ (Department of Geology, University College Cardiff, P.O. Box 78, Cardiff CF I i XL, Wales)
}

\begin{abstract}
Aвstract. Soil temperatures were recorded over periods of several weeks in the years 1969 and 1970 in two sites to a depth of $100 \mathrm{~cm}$. It was found that snow depth was of major importance in the rate of freezing of the soil in winter; where snow cover was less than $5 \mathrm{~cm}$ in depth freezing rates were almost double those where snow depth was over $1 \mathrm{~m}$. Snow cover also insulated the soil surface from above-zero air temperatures during spring, and soil thawing commenced from the surface only following the clearance of snow. Similarly, insulation of the soil surface by snow prevented short-term freezing and thawing cycles penetrating the soil, although even where snow cover was absent such short-term cycles were not observed to penetrate the soil to depths in excess of $5 \mathrm{~cm}$. This surficial freezing and thawing of the soil took place more readily in spring than in the autumn. It was concluded that the annual cycle of soil freezing and thawing was the dominant factor in the thermal regime of these soils, short-term freezing cycles affecting only the immediate surface soil layers.
\end{abstract}

RÉsumé. Températures du sol en automne, en hiver et au printemps à Okstindan, Norvège. Les températures ont été enregistrées pendant des périodes de plusieurs semaines au cours des années 1969 et 1970, dans deux sites, jusqu'à des profondeurs de $100 \mathrm{~cm}$. On a trouvé que l'épaisseur de la neige était d'une importance primordiale sur l'amplitude du gel du sol en hiver; lorsque le manteau neigeux avait moins de $5 \mathrm{~cm}$ en profondeur, la vitesse de développement de gel était, presque le double que quand la profondeur était de moins d'un mètre. Le couvert neigeux isole aussi la surface du sol des températures de l'air positives au printemps, et le dégel du sol commence à la surface seulement après la disparition de la neige. De même, l'isolation du sol par la neige empêche la pénétration dans le sol des alternances à courtes périodes de gel et de dégel, bien que, même en l'absence de couverture neigeuse, on n'ait pas observé la pénétration de tels cycles à courte périodicité à des profondeurs excédant $5 \mathrm{~cm}$. Ces alternances de gel et de dégel superficiel du sol ont lieu plus facielement au printemps qu'à l'automne. On conclut que le cycle annuel de gel et de dégel du sol est le facteur dominant dans le régime thermique de ces sols, les gels pour des cycles de courte périodicité affectant seulement les niveaux les plus superficiels du sol.

Zusammenfassung. Herbst-, Winter- und Fruhlingsbodentemperaturen in Okstindan, Norwegen. In den Jahren 1969 und 1970 wurden über Zeiträume von einigen Wochen an zwei Stellen Bodentemperaturen bis zu $100 \mathrm{~cm}$ Tiefe registriert. Es ergab sich, dass die Schneehöhe von wesentlicher Bedeutung für die Geschwindigkeit des Bodenfrostes im Winter war. Bei Schneehöhen unter $5 \mathrm{~cm}$ waren die Gefreiergeschwindigkeiten fast doppelt so gross als bei Schneehöhen über $1 \mathrm{~m}$. Die Schneedecke isolierte auch die Bodenoberfläche vor Luftemperaturen über Null im Frühling und das Auftrauen des Bodens begann von der Oberfläche her erst nach dem Verschwinden des Schnees. Ähnlich verhinderte die Isolierung des Boden durch Schnee das Eindrigen kurzzeitiger Frost- und Tauperioden in den Boden. Selbst bei Fehlen des Schneedecke liessen sich solche kurzzeitigen Perioden in Bodentiefen von mehr als $5 \mathrm{~cm}$ nicht beobachten. Dieses oberflächennahe Gefrieren und Tauen des Bodens fand eher im Frühling als im Herbst statt. Es wurde der Schluss gezogen, dass der Jahreszyklus des Bodengefrierens und -tauens der beherrschende Faktor im Wärmehaushalt dieser Böden ist, dass dagegen kurzzeitige Frostperioden nur die oberflächennächsten Schichten des Bodens beeinflussen.

THE thermal regime of soils in periglacial areas is of major significance to the geomorphological and pedological processes acting within them. As part of a detailed study of periglacial slope processes in a small area of the Okstindan mountains, an attempt was made to monitor soil temperatures. Two adjacent sites were selected for instrumentation. Particular attention was paid to recording soil temperatures during the autumn, winter and spring periods of soil freezing and/or thawing. The record of soil temperatures reported here covers periods during the autumn, winter and spring, from September ig69 to December I 970.

\section{Climate}

The Okstindan mountain range lies to the west of the Atlantic/Baltic watershed, only about $80 \mathrm{~km}$ from the sea. The area is therefore subject to a relatively maritime climate. Figure I shows stations around the Okstindan area from which meteorological data have been used and Table I gives their respective mean annual temperatures, precipitation and number of days' snow cover.

\footnotetext{
* Okstindan Research Project, Report No. 12.
} 
On the basis of altitude, Worsley and Harris (in press) have estimated that the mean annual temperature in Okstindan is around $-2.5^{\circ} \mathrm{C}$.

Brown (1960, I967) suggested that in the Arctic and sub-Arctic the $-\mathrm{I}^{\circ}$ to $-2^{\circ} \mathrm{C}$ mean annual isotherm approximates the southern limit of discontinuous permafrost, and Lundqvist ( 1962 ) put forward a similar southerly limit in the mountains of northern Sweden. Ives and Fahey (I97I) reported sporadic permafrost beneath an active layer of less than $2 \mathrm{~m}$ at the $3500 \mathrm{~m}$ level on Niwot Ridge, Colorado, where the mean annual air temperature is $-3.9^{\circ} \mathrm{C}$.

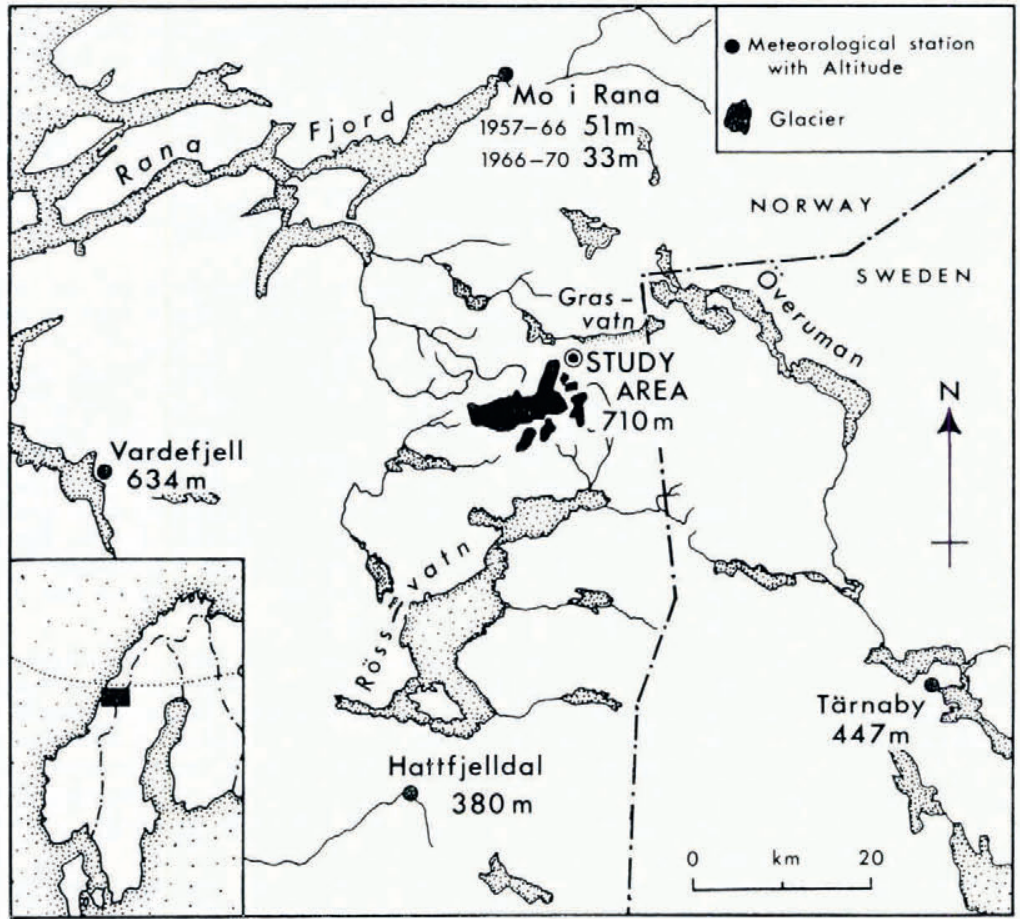

Fig. I. Location map, showing the study area and the Norwegian meteorological stations referred to in the text. Dates and heights shown for Mo $i$ Rana refer to a change in location of the meteorological station.

TABLE I

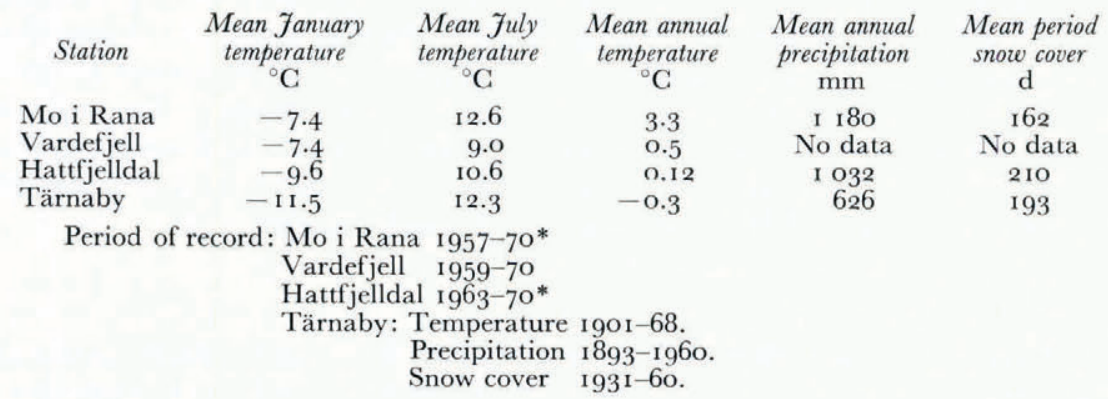

* Note that over the period quoted for Mo i Rana the location of the station was changed in 1966 , from an altitude of $5^{1} \mathrm{~m}$ to one of $33 \mathrm{~m}$. In Hattfjelldal, the location of the station was changed in 1962 , its altitude being raised from $221 \mathrm{~m}$ to $380 \mathrm{~m}$. Since this increase in altitude considerably affected climatic data from Hattfjelldal, particularly the period of snow cover, the mean values in Table I are derived only from the period since 1962 , i.e. since the station has been at $380 \mathrm{~m}$. 
The Okstindan area therefore falls within the zone of sporadic permafrost in Scandinavia. Alexander and Worsley (in press) have discussed the permafrost core of a Neoglacial moraine ridge of the outlet glacier Austre Okstindbreen, which is no more than $300 \mathrm{~m}$ from the study area considered here. However, no permanently frozen ground was encountered in excavations approaching $2 \mathrm{~m}$ in depth within the study area, and spring and summer soil-moisture conditions suggested that following clearance of ground ice within the soil to a depth of around $1.5 \mathrm{~m}$ in late spring there was no further impedance of vertical drainage (Harris, I 972 , unpublished). Since soil temperatures as high as $6.5^{\circ} \mathrm{C}$ were recorded in early September 1969 at a depth of $\mathrm{I} \mathrm{m}$, it is considered unlikely that permafrost was present, although verification of this assertion must await deeper drilling within this particular area.

\section{LOCATION}

The site for this investigation lay on the north-eastern flanks of the Okstindan mountains (Fig. I), on an east-facing slope approximately $2 \mathrm{~km}$ to the east of the outlet glacier Austre

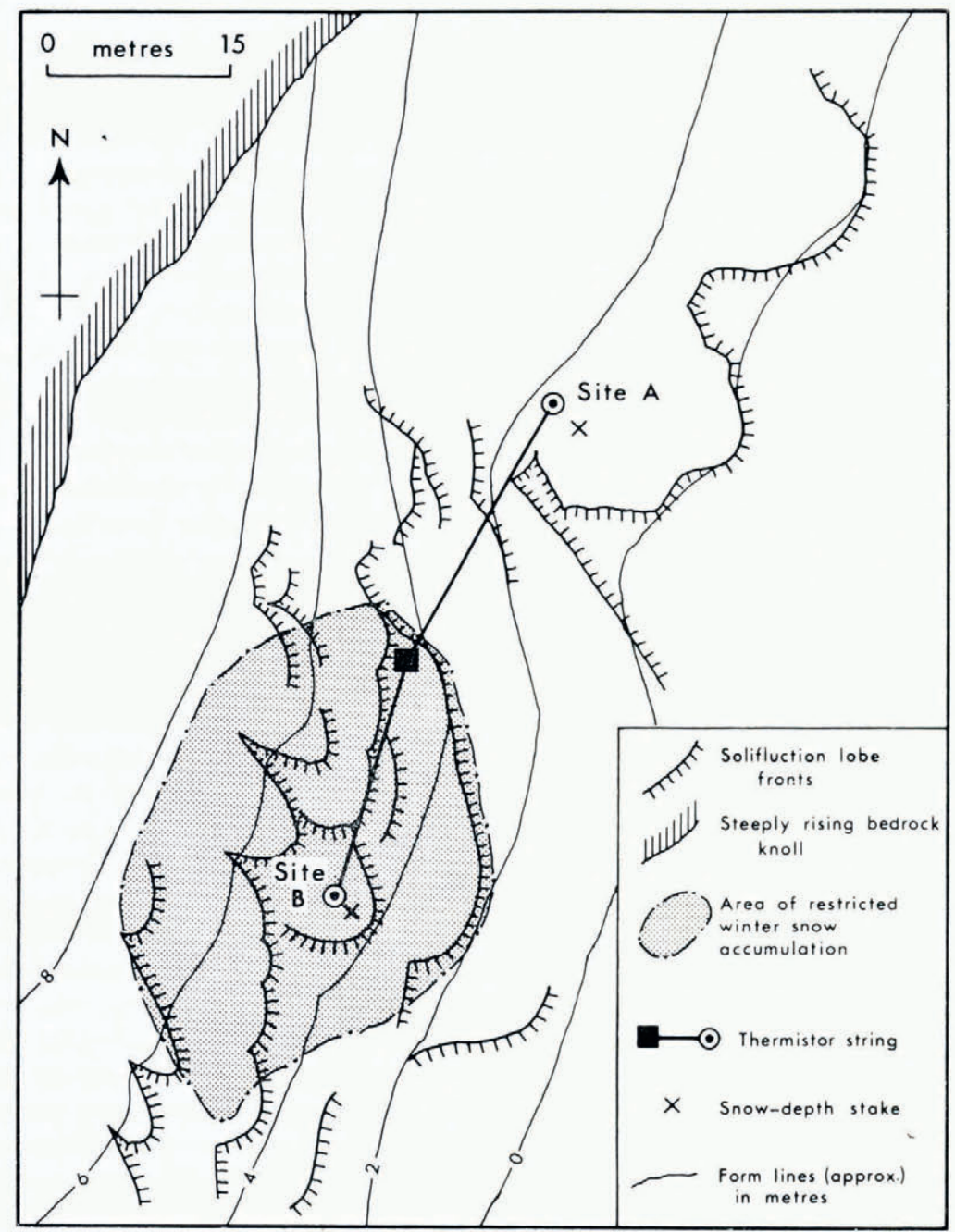

Fig. 2. The study area. 
Okstindbreen. The slope is composed of sandy till deposited against a steeply rising bedrock knoll which forms the upward limit of the slope. Snow was drifted in the lee of this knoll during winter, and the drift extended over a considerable area of the slope below (Fig. 2). Evidence for solifluction took the form of well-developed turf-banked solifluction lobes, and measurement has shown that down-slope soil movement is active under the present-day climatic conditions (Harris, 1972, I973, unpublished).

Vegetation reflected the presence of the late-lying snow patch at the head of the slope. Near the head of the slope, where snow persisted longest in summer, the vegetation was restricted to a thin moss. Farther down-slope Salix herbacea became established as the annual snow-free period increased, and this in turn gave way to a thicker heath community dominated by Arctostaphylos alpina, Vaccinium myrtillus and Carex spp.

Thin skeletal soils were developed beneath the heath vegetation, with dark A horizons of thickness up to $10 \mathrm{~cm}$ above lighter-coloured B horizons of thickness up to $16 \mathrm{~cm}$, which in turn passed into the parent till with little apparent change, except for coloration. Higher up the slope in the moss-covered area solifluction was relatively active, and little soil development was apparent (for more detailed soil descriptions see Worsley and Harris (in press)).

\section{INSTRUMENTATION}

Since the field area was unoccupied during the winter months, an automatic temperature recorder was required to monitor soil temperatures and, since no electrical power supply was available, the recorder had to be battery operated. A Grant Model D miniature recorder appeared to be suitable for this purpose, being relatively robust and inexpensive. It consisted of a multipoint recorder which scanned nine thermistors, initially with a 2 hourly cycle, giving 12 readings per day. This was reduced to a 4 hourly cycle in order to reduce the load on the battery. The manufacturer quoted an accuracy for this instrument of $\pm 2 \%$ of full scale, i.e. $\pm 0.6 \mathrm{deg}$.

The locations of the two strings of thermistors buried within the soil are shown in Figure 2, the two monitored sites being designated $\mathrm{A}$ and $\mathrm{B}$. In site $\mathrm{A}$, thermistors were placed at depths of $100,50,25,5$ and o cm below the surface, while in site B thermistors were buried to depths of 75,25 and $5 \mathrm{~cm}$. The ninth thermistor was placed in a small white aerated box $\mathrm{I} \mathrm{m}$ above the ground to record air temperatures.

\section{REsULTS}

\section{Autumn soil temperatures, 1969 and 1970}

The record for the autumn period of 1969 extends from 2 I September to 29 October. Although this gives no information on the rate of soil freezing during the winter freeze-up, it shows the general cooling of the soil in response to falling air temperatures, and provides data on diurnal freeze-thaw cycles during this part of the autumn and their effectiveness with regard to soil freezing. * Figure 3 shows the 2 hourly temperature record for the two sites over this 5 week period.

Air temperature fell below freezing on 18 occasions during late September and October. The most severe frost $\left(-6^{\circ} \mathrm{C}\right.$, sub-zero temperatures persisting for approximately $42 \mathrm{~h}$ ) followed a period of snowfall, and the soil surface in site $\mathrm{A}$ consequently did not fall to $\mathrm{O}^{\circ} \mathrm{C}$ throughout this period. In site B the snow was blown off the area and insulation of the soil surface was therefore restricted. However, in this location the soil temperature at $5 \mathrm{~cm}$ depth remained above freezing. Throughout the period of records soil freezing did not penetrate to $5 \mathrm{~cm}$ depth in either area, although towards the end of October when snow cover

* For the purpose of this account, soil freezing will be assumed to take place at $0^{\circ} \mathrm{C}$; in a sandy deposit such as this, such an assumption is probably within the limits of accuracy to which temperatures were recorded. 


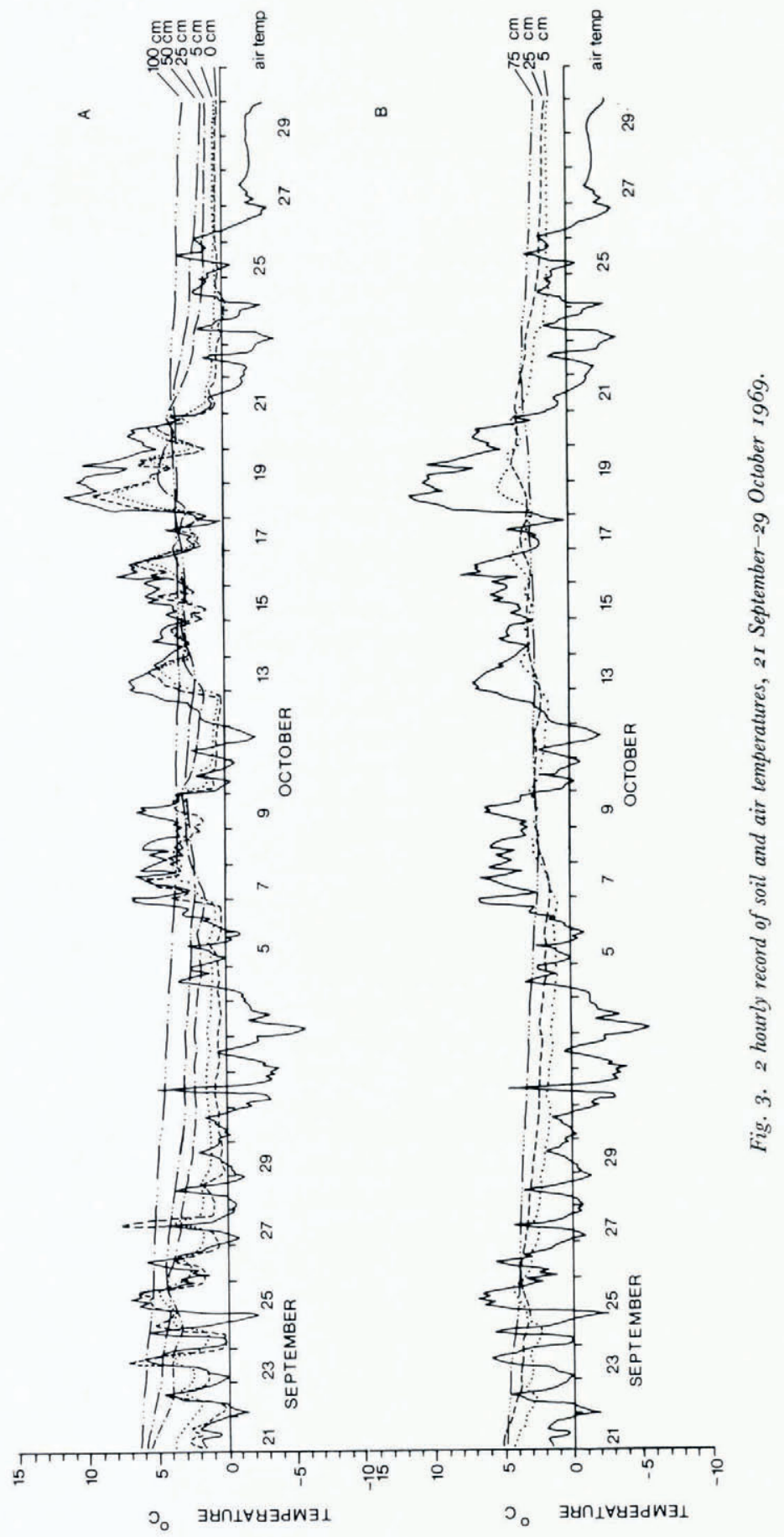


was absent the soil surface in site A did register sub-zero temperatures in response to shortterm fluctuations of air temperature about $\mathrm{O}^{\circ} \mathrm{C}$.

The time lag between air-temperature variation and corresponding soil-temperature variation is illustrated in these two sets of temperature recordings. Product-moment correlation coefficients were calculated between air temperatures and soil temperatures for the period 2 I-27 September 1969, when no soil freezing took place and no snow cover was present. The soil temperatures were then stepped back in time by one time unit $(2 \mathrm{~h})$ and correlation coefficients were again calculated. This process was repeated 19 times and the time lag giving the maximum value of $r$, the correlation coefficient, between air temperature and temperature at each depth in the two soil profiles was taken as representing the lag between air-temperature fluctuation and corresponding soil-temperature fluctuation. A mean time lag of $2 \mathrm{~h}$ was found at $5 \mathrm{~cm}$ in site A which increased to $\mathrm{Io} \mathrm{h}$ at $25 \mathrm{~cm}$, compared with a lag of $4 \mathrm{~h}$ at $5 \mathrm{~cm}$ in site B, and $\mathrm{I} 4 \mathrm{~h}$ at $25 \mathrm{~cm}$ (Harris, unpublished). Since the temperatures were recorded at 2 hourly intervals, these time lags can only be quoted to the nearest $2 \mathrm{~h}$. The longer delay in soil-temperature adjustment to air-temperature fluctuation observed in site B was considered to be due to the thicker vegetation cover over site B providing a more efficient insulation of the soil surface. This situation was of course reversed later in the year, when snow cover was present, by the much greater accumulation of snow which occurred at site A.

A rather longer period was monitored during the autumn of 1970 , extending well into the winter freeze-up when air temperatures were constantly below freezing. Figure 4 shows air and soil temperatures from the two sites over the period from 27 September to 8 November 1970. The air temperature fluctuated above and below freezing on 13 occasions until $3^{\mathrm{I}}$ October when sub-zero temperatures were established until the end of the recording period ( 12 December). None of these short-term freeze-thaw cycles of air temperature caused soil freezing at $5 \mathrm{~cm}$ depth in either site, although the soil surface in site A registered zero and sub-zero temperatures on 12 occasions before the winter freeze-up of the soil set in. As in I 969 , during the most severe frost of the autumn $\left(-\mathrm{I} I .2^{\circ} \mathrm{C}\right)$ a thin snow cover maintained soil temperatures above freezing, the soil surface temperature in site A falling to only $-0.2^{\circ} \mathrm{C}$.

\section{Winter soil temperatures, $1969-70$ and $1970-71$}

The effect of snow depth on the rate and severity of soil freezing during the winter has already been discussed (Harris, I972) and only a brief summary need be given here. In site A the snowdrift extended across the thermistor location and snow depth was up to $\mathrm{I} .5 \mathrm{~m}$, while in site B wind action swept the area almost clear of snow and a maximum thickness of only $5 \mathrm{~cm}$ was recorded.

Table II shows soil and air temperatures recorded on 25 January and 4 April 1970 when the field area was re-visited. A contrast in soil temperatures between the two sites is immediately apparent, site $\mathrm{B}$ recording a temperature $10^{\circ} \mathrm{C}$ lower than that in site $\mathrm{A}$ at the

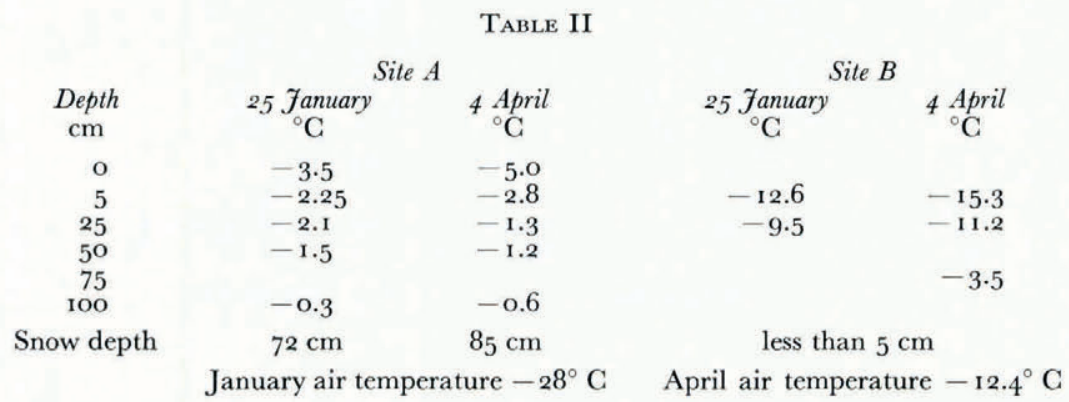


SOIL TEMPERATURES IN OKSTINDAN, NORWAY

527

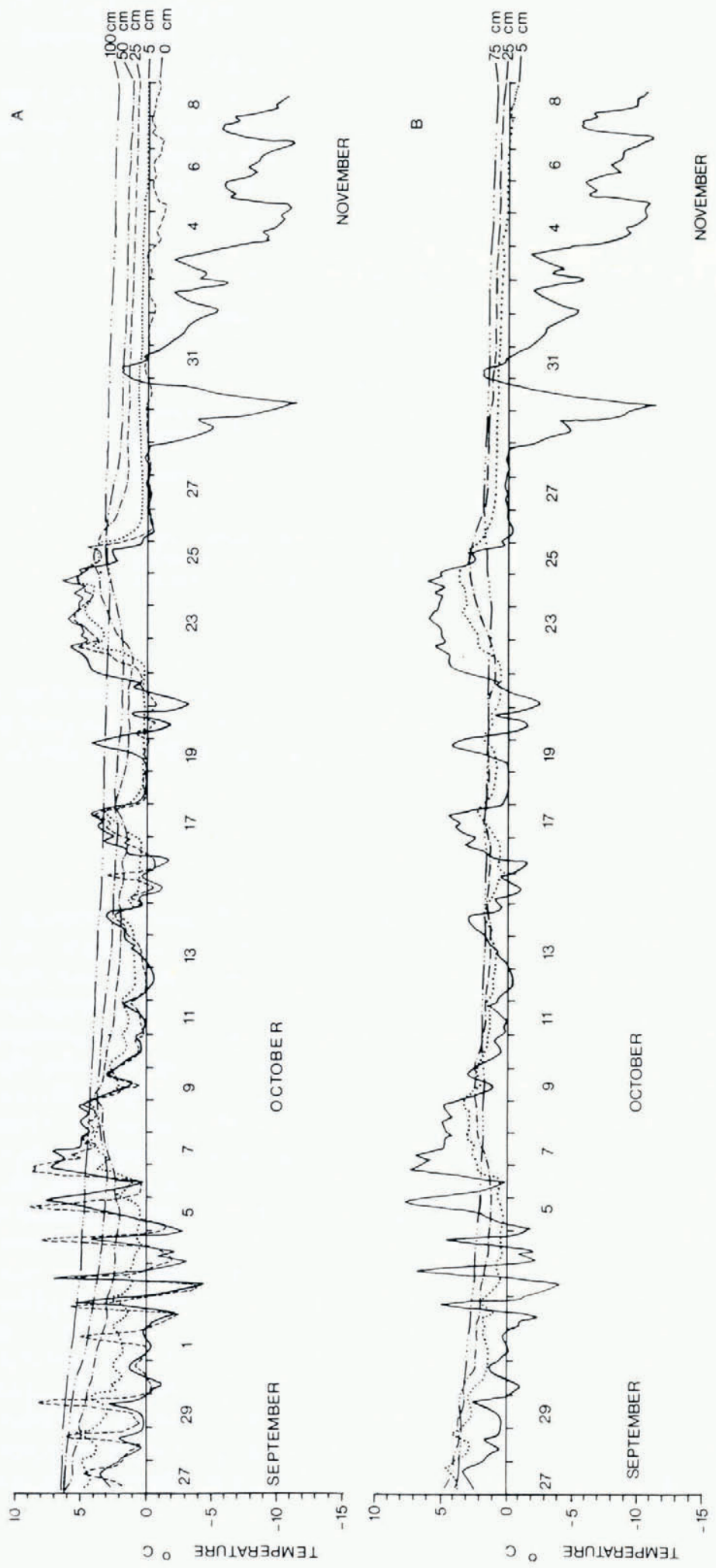

https://doi.org/10.3189/S002214300002325X Published online by Cambridge University Press 
$5 \mathrm{~cm}$ depth in January, and $12.5^{\circ} \mathrm{C}$ lower at the same depth in April. From these soil temperatures it was estimated that soil freezing took place to a depth of around $\mathrm{I} .5 \mathrm{~m}$ in site A and to a somewhat greater depth in site B during this winter.

The soil-temperature record for the early winter of $1970-7 \mathrm{I}$ also revealed the effectiveness of the thicker snow cover in site $\mathrm{A}$ in restricting the rate of heat loss by the soil. Table III shows the dates at which each thermistor in the two sites first registered $o^{\circ} \mathrm{C}$, from which the average rate of penetration of the freezing plane may be calculated.

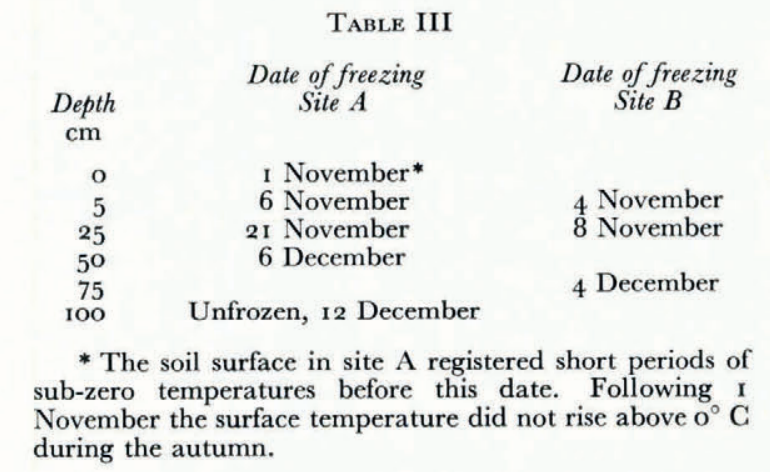

The average rate of penetration of the freezing plane in site $\mathrm{A}$ from $\mathrm{o} \mathrm{cm}$ to $50 \mathrm{~cm}$ was found to be $1.23 \mathrm{~cm}$ per day, and for site $\mathrm{B}$, from $5 \mathrm{~cm}$ to $75 \mathrm{~cm}, 2.33 \mathrm{~cm}$ per day. The freezing of the soil in site B therefore took place almost twice as fast as in site A, reflecting the contrast in snow conditions in the two sites.

\section{Spring soil temperatures, 1970}

The edge of the snow patch did not retreat above the thermistor location in site $\mathrm{A}$ until 27 May, and its influence on soil temperatures in this site is clearly shown in Figure 5; soil thawing from the surface as a result of above-zero air temperatures was delayed until the snow cleared. However, it is interesting to note that the $100 \mathrm{~cm}$ depth registered above-zero temperatures before this date, suggesting thawing from below due to geothermal heat. In site B no snow cover was present at the beginning of the record and thawing from the surface was in progress throughout the monitored period. During the spring the thermistor at $25 \mathrm{~cm}$ below the surface in site B failed to yield any results. Soil thawing in site B reached $5 \mathrm{~cm}$ by 9 May (readings taken at mid-day on 4-8 May showing sub-zero temperatures at this depth), and the $75 \mathrm{~cm}$ thermistor registered positive temperatures for the first time on I2 June.

During May, soil temperatures in site $\mathrm{B}$ fell to $\mathrm{o}^{\circ} \mathrm{C}$ on seven occasions as a result of nocturnal cooling of the soil, including the nights of I I and I2 May when air temperatures remained above zero and cooling was probably from below rather than from above. The thaw observed at $5 \mathrm{~cm}$ from 4 to 9 May could possibly represent the final phase of an earlier short-term freeze-thaw cycle penetrating the soil more deeply than those observed subsequently. However, the soil at this depth registered $-\mathrm{I} 5.3^{\circ} \mathrm{C}$ on 4 April and it is unlikely that sufficiently high air temperatures could have prevailed later in the month to cause warming and thawing before a short-term freezing cycle could penetrate to a similar depth. It is concluded therefore that the thaw observed up to 9 May at $5 \mathrm{~cm}$ in site B represented the end of the winter freezing cycle at that depth rather than the final phase of a short-term cycle. 


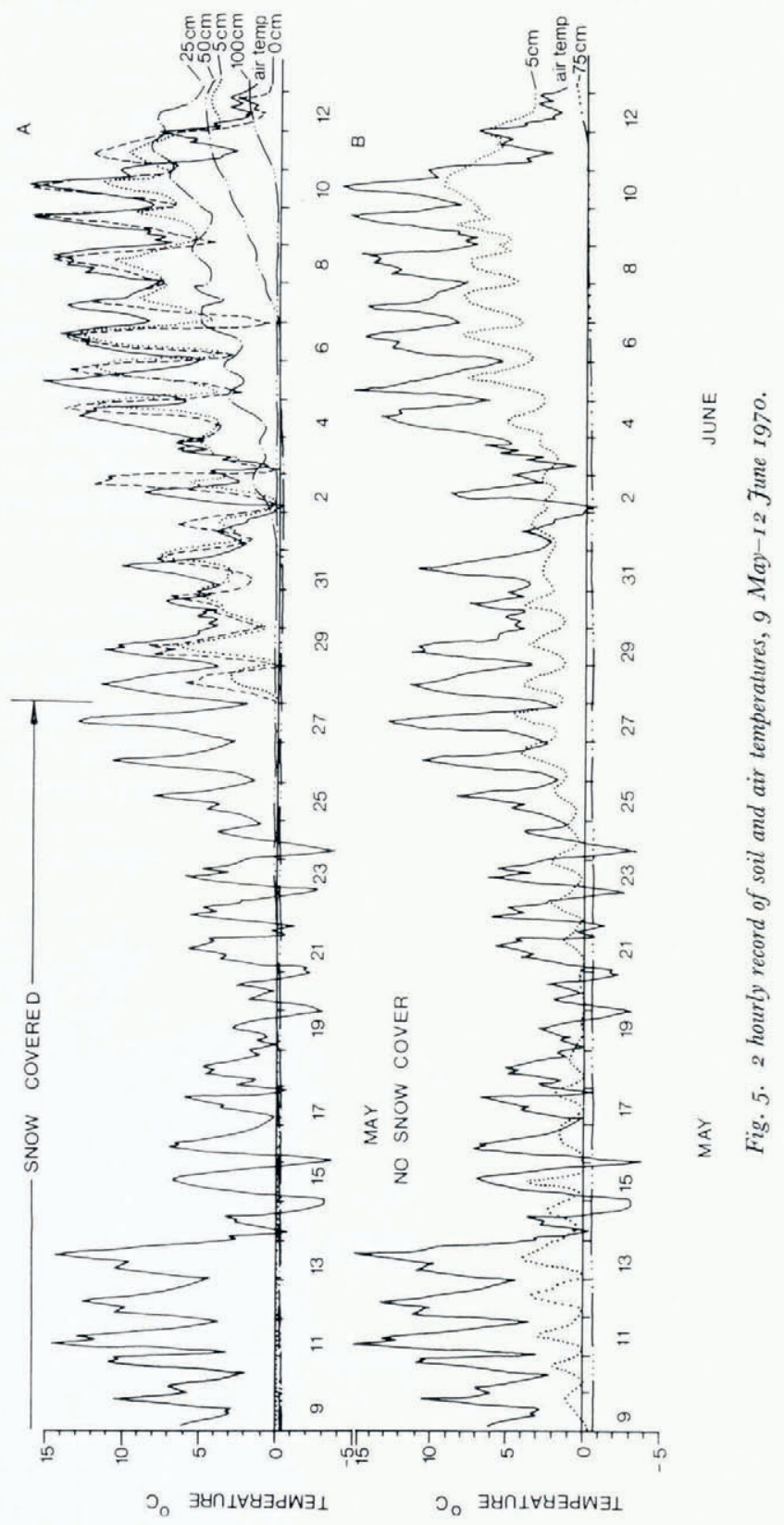




\section{Discussion}

Two important aspects of the thermal regime of the soils in Okstindan are illustrated by this study. First, the depth of snow cover during the autumn and winter is of major importance in controlling the depth and severity of freezing in the soil. Atkinson and Bay (1940) found that the depth of freezing was inversely proportional to the depth of snow, and Gold (1958), working in the Ottawa area, concluded that the heat flow from the ground varied inversely with the depth of snow cover. In Okstindan, during early winter 1970, it was observed that soil freezing beneath a snow cover of only a few centimetres took place almost twice as fast as beneath a snow cover which by April I97 I had reached $130 \mathrm{~cm}$ in thickness.

In an attempt to assess the representativeness of the two years $1969-70$ and $1970-71$, with regard to snow cover in this area of northern Norway, recourse may be made to data from the nearest inland Norwegian meteorological station, at Hattfjelldal, about $50 \mathrm{~km}$ to the south. Here there were 206 days with snow cover in the winter of $1969-70$ and 190 days in the winter of $1970-71$, compared with an average of 210 days for the period $1963-71$. Assuming that the relative amounts of snowfall in these two winters was similar in Okstindan to that recorded in Hattfjelldal, it may be concluded that the snow conditions during $1969-70$ were close to average, and in the following year the duration of snow cover was rather below average. It is unlikely therefore that soil-temperature data obtained during these two winters would have over-emphasized the importance of snow cover, and in the second winter the converse may well be true.

The significance of snow cover to the rate and depth of winter soil freezing is important in Okstindan, for here snow arrives relatively early in the autumn and melts relatively late in the spring. Above the tree line, wind action is unimpeded and drifting of snow takes place. Hence the snow depth is likely to vary considerably, with exposed ridges bearing but a thin cover of ice while the intervening hollows have a considerable snow accumulation (Fig. 6). Such variations in snow depth are probably associated with variations in the severity and depth of winter soil freezing similar to those described here, and such variations may be of considerable significance to surface micro-topography, and internal structure of the soils.

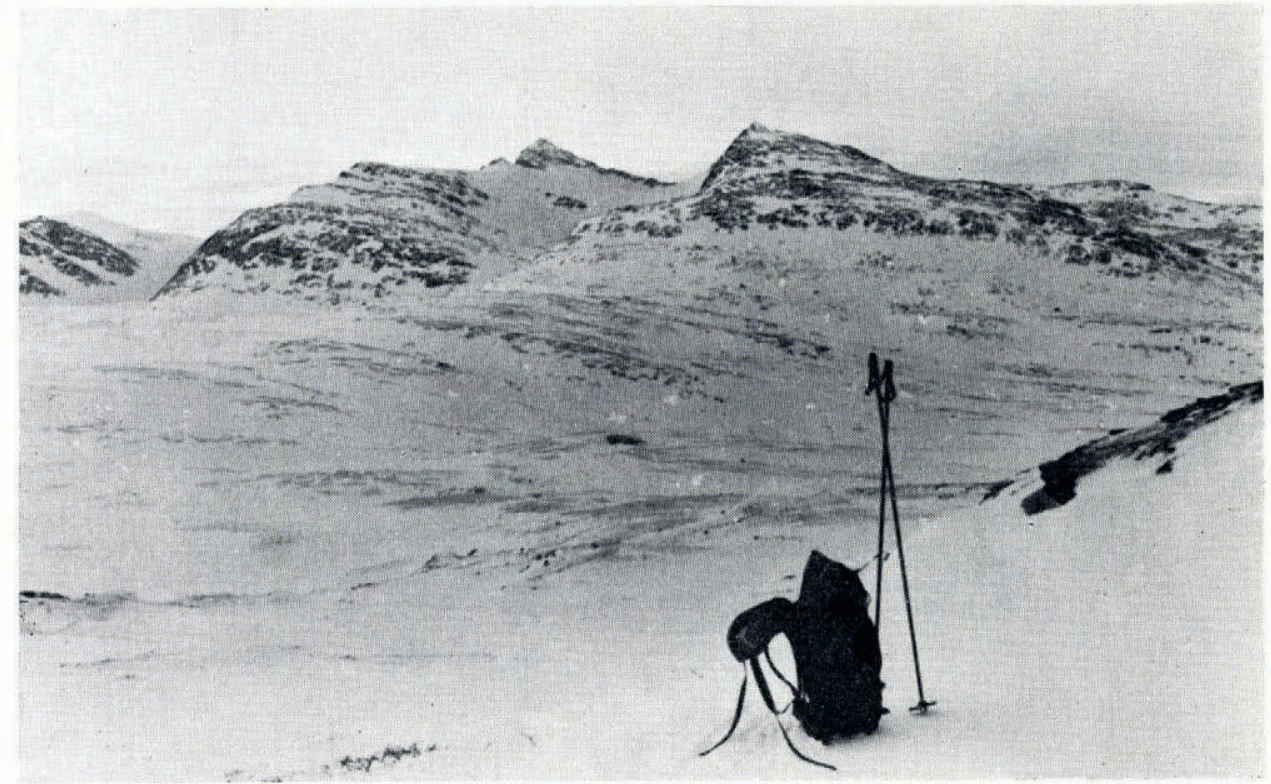

Fig. 6. The northern flanks of Okstindan, 4 April 1970. (Photograph by G. Rosvol.) 
The second important aspect of the thermal regime of Okstindan soils which is much affected by snow depth is the effectiveness of short-term freeze-thaw cycles of air temperature in causing freezing and thawing of the soil. In site A, where snow arrived early in the autumn and lasted until late in the spring, the annual winter freezing cycle was the only freeze-thaw event to penetrate the soil. In site B, where snow cover was greatly restricted, no short-term freezing cycles were recorded at the $5 \mathrm{~cm}$ depth during the autumn periods of record, although several cycles of zero temperatures penetrated the soil to a depth of $5 \mathrm{~cm}$ during the spring thaw period. The lack of freeze-thaw cycles in the autumn was probably due to the sensible heat stored in the soil following the summer which had to be removed before freezing could commence. During the spring, no such stored summer heat was present within the soil, and therefore the nocturnal cooling to which the soil surface was subjected was sufficient to cool it to freezing point and freezing to commence. Such short-term freezing cycles could affect only the near-surface soil layers, and probably did not penetrate below $5 \mathrm{~cm}$ depth in the soil. A more severe and prolonged period of sub-zero air temperatures would clearly have caused more extensive refreezing of the soil, but even under these conditions the depth of refreezing would be limited to the depth of penetration of spring thaw in the soil. By 9 May I 970 this depth was only $5 \mathrm{~cm}$ in site B, and it did not reach $75 \mathrm{~cm}$ until 12 June, by which time severe freezing temperatures were unlikely.

Before final conclusions may be drawn from these two winters, it is necessary to compare their air temperatures with the average conditions, and reference will again be made to Hattfjelldal. Although the altitudinal difference probably resulted in winter temperature several degrees lower in Okstindan, comparison of the Hattfjelldal data with the corresponding averages for the station provides an indication of the relative severity of these two winters in this general area. From Figure 7 it can be seen that the first winter was slightly cooler than average, while the second was somewhat warmer than average in the months of December, January and February. During the respective springs and autumns, when short-term freeze-thaw cycles might be expected, both years varied only slightly from the mean, suggesting that the monitored periods provide a reasonably representative picture of the thermal conditions within the soils of Okstindan during spring and autumn.

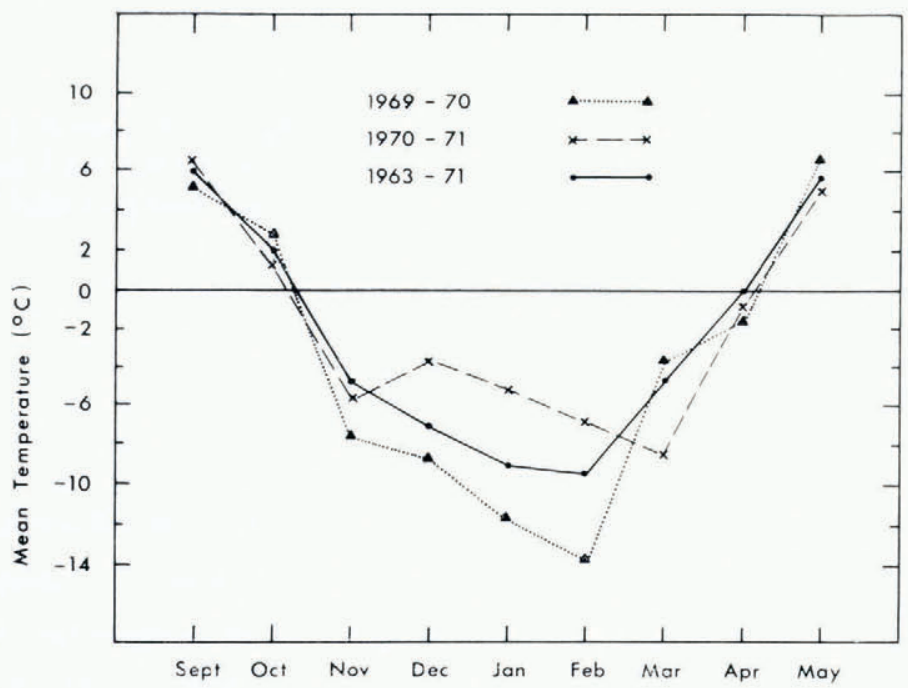

Fig. 7. Mean monthly temperatures, September-May, Hattfjelldal, 1963-71, 1969-70 and I970-7I. 


\section{Conclusions}

Although data are available for relatively short periods only, certain aspects of the thermal regime of the soils in the study area were revealed in this study. The importance of snow cover in insulating the soil was clearly demonstrated by the contrast in winter soil temperatures between the two monitored sites. Where thick snow was present, the rate of penetration of the freezing plane through the soil from the surface was greatly reduced. In Okstindan, drifting of snow occurs above the tree line, resulting in considerable variations in snow depth over relatively small areas, and frost penetration into the soil must likewise vary considerably. In addition, the presence of snow cover delayed the thawing of the soil in spring until the snow itself had cleared.

The differences between the thermal regimes of the soils of snow-accumulation areas and the soils of exposed wind-swept ridges observed in this study must at least in part explain contrasts in morphology, vegetation and soil characteristics between such areas. For instance, frost-cracking of the turf is commonly observed where deflation prevents snow accumulation, and marked differences in the amount of frost-heaving of the soil during winter have been observed between snow-accumulation and snow-free sites (Harris, 1972, 1973).

Short-term freezing and thawing cycles within the soil were found to be restricted to the surficial layers only, and were not recorded below $5 \mathrm{~cm}$ depth. The comparatively early arrival of snow and its prolonged stay over much of the area effectively prevented short-term oscillations of air temperature from affecting the soil temperatures considerably. Even where snow depth was thin and cleared early in the spring, it appeared that the cycles of nocturnal cooling were insufficiently prolonged or severe to cause penetration of soil freezing much below the surface. It was observed, however, that when surface freezing did occur its depth was greater during spring than during autumn.

This study suggests therefore that freezing and thawing of the soil in this area of Norway is restricted to the annual cycle of autumn freezing and spring thawing, and that short-term cycles are of minor importance. Similar conclusions were drawn from observations in Arctic Canada by Cook ([1966]). The morphological significance of this absence of short-term and frequent freeze-thaw cycles in the soil is shown by the absence of well-developed sorted patterned ground in Okstindan, even in areas where vegetation is greatly restricted, such as between the Neoglacial ice limits and the modern glacier margins.

\section{Acknowledgements}

Other members of the University of Reading Okstindan Research Group provided valuable assistance with field work. Herr Gunnar Røsvol visited the field area and checked the instruments during the winter months. Financial support was provided by the Natural Environment Research Council, London.

\section{MS. received 29 November 1973 and in revised form ${ }_{15}$ March 1974}

\section{REFERENCES}

Alexander, M. J., and Worsley, P. In press. On the stratigraphy of a neoglacial end moraine, Austre Okstindbredal, north Norway. Boreas.

Atkinson, H. B., and Bay, C. E. 1940. Some factors affecting frost penetration. Transactions of the American Geophysical Union, i940, Pt. 3, p. 935-47.

Brown, R. J. E. 1960. The distribution of permafrost and its relation to air temperature in Canada and the U.S.S.R. Arctic, Vol. I3, No. 3, p. $163-77$.

Brown, R. J. E. 1967. Comparison of permafrost conditions in Canada and the U.S.S.R. Polar Record, Vol. I3, No. 87 , p. $741-51$. 
Cook, F. A. [1966.] Patterned-ground research in Canada. (In Proceedings. Permafrost international conference, II-I5 November 1963 , Lafayette, Indiana, presented by Building Research Advisory Board ... at Purdue University. Washington, D.C., p. 128-30. (National Academy of Sciences-National Research Council Publication No. 1287.$)$ )

Gold, L. W. 1958. Influence of snow cover on heat flow from the ground. Some observations made in the Ottawa area. Union Géodésique et Géophysique Internationale. Association Internationale d'Hydrologie Scientifique. Assemblée générale de Toronto, 3-14 sept. 1957, Tom. 4, p. 13-21.

Harris, C. 1972. Processes of soil movement in turf-banked solifluction lobes, Okstindan, northern Norway. Institute of British Geographers. Special Publication No. 4, p. 155-74.

Harris, C. 1973. Some factors affecting the rates and processes of periglacial mass movements. Geografiska Annaler, Vol. 55A, No. I, p. 24-28.

Harris, C. Unpublished. Solifluction processes on a till slope in Okstindan, north Norway. [Ph.D. thesis, University of Reading, I972.]

Ives, J. D., and Fahey, B. D. I971. Permafrost occurrence in the Front Range, Colorado Rocky Mountains, U.S.A. Fournal of Glaciology, Vol. 10, No. 58, p. 105-11.

Lundqvist, J. 1962. Patterned ground and related frost phenomena in Sweden. Sveriges Geologiska Undersökning, Avhandlingar och Uppsatser, Ser. C, Nr. 583 , Arsbok 55, No. 7.

Worsley, P., and Harris, C. In press. Evidence for neoglacial solifluction in Okstindan, north Norway. Arctic. 